Persp. Teol. 38 (2006) 231-250

\title{
O CONCÍLIO VATICANO II OU A IGREJA EM CONTÍNUO AGGIORNAMENTO*
}

\author{
Mario de França Miranda SJ
}

RESUMO: O artigo examina textos do Concílio Vaticano II na perspectiva do diálogo e do aggiornamento, como chave principal de leitura do mesmo. Os três temas estudados, a saber, Igreja e ecumenismo, Igreja e diálogo inter-religioso e Igreja e cultura, demonstram que a atualização permanente da Igreja passa necessariamente pelo diálogo com as comunidades evangélicas, com as religiões não cristãs e com a cultura do tempo. Para tal se expõe gradualmente ao longo do artigo como isto aconteceu durante o evento conciliar, no período pós-conciliar e como repercutiu em nosso país.

PALAVRAS-CHAVE: Vaticano II; aggiornamento; ecumenismo; religiões não cristãs; cultura.

ABSTRACT: The article examines texts of the Second Vatican Council in the perspective of dialogue and of updating as principle keys to its reading. The three themes studied are the Church and ecumenism, the Church and interreligious dialogue, and the Church and culture. The themes demonstrate that the permanent updating of the Church occurs necessarily through dialogue with the evangelical communities, with the non-christian religions and with the culture in its temporal context. For this purpose it is explained gradually along the course of the article how this happened during the Council, in the post-conciliar period and how it has reverberated in our country.

KeY-WorDS: Second Vatican Council; Aggiornamento; Ecumenism; Non-christian religions; Culture.

* Texto de uma palestra dada no "Seminário Comemorativo dos 40 anos do Concílio Vaticano II”, ocorrido em Itaici, de 08 a 10 de fevereiro de 2006. 


\title{
I. O sonho de João XXIII: Aggiornamento e diálogo
}

\begin{abstract}
reflexão que me foi pedida, por abranger temas tão diversos como A ecumenismo, diálogo inter-religioso e cultura no Concílio Vaticano II, requer de início uma chave interpretativa que permita fazer emergir o que todos eles têm de comum. Pois só assim chegaremos à raiz de onde brotaram, conheceremos o contexto onde se situam e ganharemos maior compreensão dos mesmos. Um objetivo fácil de se exprimir, mas tremendamente difícil de se concretizar. Pois buscar uma perspectiva de leitura destes temas, enquanto apresentados pelo Concílio Vaticano II, implica necessariamente entrar no complexo debate sobre a correta interpretação deste mesmo Concílio, sobre o que foi sua recepção real com seus acertos e desvios, sobre a fidelidade ou não a seu espírito. Naturalmente esta discussão extrapola a intenção de nosso estudo, tendo sido tratada com maestria e perícia noutra conferência deste seminário.
\end{abstract}

Mas o problema de encontrar uma perspectiva de fundo que elimine de antemão a impressão de tratarmos de temas disparatados e justapostos, sem qualquer conexão interna, continua nos urgindo a pensar numa saída. Vamos nos deixar guiar pelo que poderíamos chamar de "o sonho de João XXIII". Duas palavras sintetizam o que pretendia com o Concílio: aggiornamento e diálogo, como bem observou um insigne participante do mesmo ${ }^{1}$. Duas realidades que se completam, mas que também se implicam mutuamente. Elas nos ajudarão a descobrir em temas aparentemente tão diversos como os nossos o mesmo dinamismo de fundo, embora se manifestando em configurações diferentes.

Aggiornamento significa atualização, renovação, reforma mesmo. Pressupõe primeiramente um descompasso da Igreja com a sociedade envolvente, uma dificuldade mais experimentada e sentida do que formulada de proclamar na cultura de então a mensagem evangélica, uma convicção firme do fim de uma configuração histórica do catolicismo ${ }^{2}$. De fato, os limites da era pós-tridentina se faziam sentir. O Concílio de Trento teve o grande mérito de represar a ameaça de fragmentação da Igreja. Mas representou também um catolicismo romano afastado das outras tradições cristãs do ocidente e do oriente, entrincheirado diante da cultura moderna, e avesso ao contato com outras culturas nativas ${ }^{3}$. Para João XXIII não se tratava, portanto, de corrigir erros doutrinais ou morais, como acontecera nos

\footnotetext{
${ }^{1}$ A. LORSCHEIDER, "Introdução", in P.S. LOPES GONÇALVES / V.I. BOMBONATTO (orgs.), Concílio Vaticano II. Análise e prospectivas, S. Paulo: Paulinas, 2004, p. 6.

${ }^{2}$ G. ALBERIGO, "La condition chrétienne après Vatican II", in G. ALBERIGO / J.-P. JOSSUA (orgs.), La réception de Vatican II, Paris: Cerf, 1985, p. 28.

${ }^{3}$ Ibidem, p. 26.
} 
Concílios Ecumênicos anteriores. Fazia-se mister atualizar a mensagem da salvação procurando exprimi-la para o mundo moderno. Aqui se situa a originalidade do Concílio Vaticano II $^{4}$.

Tarefa difícil que exige sério discernimento para não sacrificar elementos substanciais da fé cristã, como já alertara o próprio pontífice em sua alocução Gaudet Mater Ecclesia de 11 de outubro de $1962^{5}$, embora esta distinção tenha se mostrado de maior complexidade nos anos seguintes. Pois, o caráter pastoral da doutrina dificulta a distinção clássica entre doutrina e disciplina ou dogma e heresia. Trata-se de um adjetivo que engloba doutrina e disciplina, e vai além. Pois ele indica que o destinatário da mensagem evangélica deve ser levado a sério para poder captar esta mensagem. $\mathrm{O}$ que implica que seu contexto histórico e cultural seja respeitado, resultando daí uma configuração atualizada da verdade revelada ${ }^{6}$.

É a partir daqui que se pode entender a afirmação de alguns de que este é um Concílio de transição ${ }^{7}$. Não no sentido de uma desvalorização de seu texto em nome do "espírito" que o animava, como se pudesse chegar a este prescindindo daquele. Mas enquanto indica aos vindouros que a tarefa de atualização prossegue e deve prosseguir para que a Igreja continue sendo o sacramento da salvação de Jesus Cristo ao longo da história. Mesmo que ela experimente temporariamente certo desequilíbrio, como já aconteceu com Concílios anteriores. O aggiornamento e a pastoralidade influenciaram fortemente os Padres conciliares, mas tiveram dificuldade em serem traduzidos e expressos nos textos, criando assim um hiato entre o evento conciliar e as decisões finais da assembléia ${ }^{8}$. Já foi sugerida mesmo a distinção entre o texto do Concílio, a experiência que tiveram seus participantes e o evento conciliar, que se constitui como tal somente no juízo que dele farão as gerações futuras ${ }^{9}$. Não nos compete entrar aqui no conflito de interpretações que marcou o período pós-conciliar ${ }^{10}$.

${ }^{4}$ F. CATÃO, "O perfil distintivo do Vaticano II: recepção e interpretação", in LOPES GONÇALVES / BOMBONATTO, op. cit., p. 101.

${ }^{5}$ Assim se exprime João XXIII no texto original em italiano: "Altra è la sostanza dell'antica dottrina del depositum fidei, ed altra è la formulazione del suo rivestimento: ed è di questo che devesi - con pazienza se occorre - tener gran conto, tutto misurando nelle forme e proporzioni di un magistero a carattere prevalentemente pastorale" (n.15). Ver A. RAMÍREZ, "A los cuarenta años de la inauguración del Concilio Vaticano II", Cuestiones Teológicas 30 (2003) 29-55, aqui p. 49.

${ }^{6}$ Ch. THEOBALD, "As opções teológicas do Concílio Vaticano II: em busca de um princípio interno de interpretação", Concilium (2005) 115-138, aqui p. 128.

${ }^{7}$ H.J. POTTMEYER, "Vers une nouvelle phase de réception de Vatican II", in ALBERIGO / JOSSUA, op. cit., p. 52.

${ }^{8}$ G. ALBERIGO, "O Vaticano II e sua história", Concilium (2005) 7-19, aqui p. 17.

9 J. KOMONCHAK, "Vatican II as an event", Theology Digest 46 (1999) 337-352.

${ }^{10}$ Para uma resenha atualizada, ver A. MELLONI, "O que foi o Vaticano II? Breve guia para os juízos sobre o Concílio”, Concilium (2005) 34-59. 
A outra palavra-chave para uma correta compreensão do Concílio Vaticano II é o termo diálogo. Uma realidade intimamente conexa e exigida pelo aggiornamento e pela pastoralidade. Para que a sociedade perceba o significado profundo, a dimensão salvífica, bem como a razão de ser da Igreja, é necessário que a própria Igreja conheça bem seu público. Daí se impor o diálogo como instrumento deste conhecimento. Ao entrar em diálogo com seu interlocutor a Igreja não apenas fala, mas também escuta, aprende, se repensa, se questiona, se modifica, se atualiza. Sua autocompreensão se enriquece, se renova, se faz mais transparente em sua instituição. $O$ diálogo é uma realidade profunda e exigente que leva a sério a história, a subjetividade, a sede de comunhão ${ }^{11}$. Mas foi exatamente isso que quis João XXIII para que a Igreja realizasse sua missão salvífica.

O diálogo rompe com a idéia de uma Igreja voltada para si mesma, bastando-se a si mesma, identificando a verdade revelada com seus pronunciamentos e normas, sem ter em conta a origem histórica e contextualizada dos mesmos. O diálogo recoloca em primeiro plano o sentido último da instituição eclesial como sacramento da salvação para o mundo, fazendoa entrar seriamente no desenrolar histórico da humanidade, participar da aventura humana, conviver em sociedade e construir o futuro. O diálogo para fora ganha credibilidade através do diálogo no interior da própria Igreja, pois também em seu seio a subjetividade, a historicidade e a comunidade devem poder emergir e plasmar sua própria fisionomia.

Os textos deste Concílio confirmam à saciedade como estava presente nos participantes o imperativo do diálogo. Este atinge todos os setores e atividades, pessoas e obras, como nos atestam os vários documentos. Seja dentro da Igreja, estimando e reconhecendo as legítimas diversidades (GS 92), seja dos bispos com os sacerdotes (CD 28) ou dos sacerdotes com os leigos (AA 25), ou mesmo dos leigos com outros leigos (AA 31; GS 43). Este diálogo se dá também com a sociedade (GS 92), devendo ser realizado por todos na Igreja: bispos (GS 43; CD 13), sacerdotes (PO 12; 19), seminaristas (OT 19) e leigos (AA 14). Ele é expressamente recomendado nos países de missão (AG 11), no trato com os irmãos separados (UR 11; 19), com as outras religiões (NA 2) ou culturas (AG 34) e até com os incrédulos em vista da construção da sociedade (GS 21).

Aggiornamento e diálogo constituem, portanto, o eixo em torno do qual os temas do ecumenismo, das religiões e das culturas irão se estruturar e deixar assim aflorar a unidade de fundo que os une. Depois do que vimos é evidente que não estaremos violentando ou deturpando o sentido genuíno dos mesmos. Pelo contrário. Pois é exatamente desta raiz que estes

${ }^{11}$ A. LORSCHEIDER, "Linhas mestras do Concílio Vaticano II", in A. LORSCHEIDER et alii, Vaticano II 40 anos depois, S. Paulo: Paulus, 2005, pp. 41-43. 
temas brotaram, foram entendidos pelos Padres conciliares e conseguiram suas expressões ${ }^{12}$. Esta será a perspectiva de fundo da nossa reflexão que sempre nos deverá acompanhar, seja ao examinarmos o contexto do próprio Concílio, seja ao estudarmos o tempo pós-conciliar, seja ainda ao considerarmos sua repercussão em nossa realidade. Esta tríplice seqüência será examinada em cada um dos temas: aggiornamento e diálogo com os irmãos separados, com as outras religiões e com as culturas.

\section{O diálogo ecumênico}

O decreto Unitatis Redintegratio do Concílio Vaticano II representa uma realização concreta do desejo de João XXIII. Não iremos entrar em todos os numerosos e por vezes disputados aspectos do mesmo. Reconhecemos, isto sim, neste texto um passo novo ${ }^{13}$ e corajoso da Igreja, embora signifique o início de uma caminhada que deve prosseguir. De fato, o que pretende o documento é promover a reintegração da unidade (UR 1) através do diálogo com os cristãos não católicos romanos. Entretanto, este diálogo não deixará de repercutir no interior da própria Igreja Católica, levando-a a uma renovação de cunho espiritual e institucional na medida em que ela acolhe os elementos eclesiais presentes em outras Igrejas e comunidades cristãs ${ }^{14}$. Portanto, diálogo e aggiornamento caminham juntos, implicandose mutuamente. Esta será a linha condutora de nossa reflexão.

Antes de tudo um dado é aqui fundamental. Trata-se do reconhecimento por parte da Igreja do assim chamado movimento ecumênico, que surgiu e se desenvolveu fora dela e que no passado foi olhado com reservas. Ela o faz ao afirmar ser este movimento deslanchado pelo próprio Espírito Santo. "E também, por graça do Espírito Santo, surgiu, entre nossos irmãos separados, um movimento sempre mais amplo para restaurar a unidade de todos os cristãos" (UR 1). Ela capta deste modo a vontade de Deus através da leitura de um dos sinais dos tempos.

Pressuposto decisivo para a entrada da Igreja no diálogo ecumênico foi a compreensão de si própria como de uma comunhão. Pois enquanto se considerava juridicamente uma sociedade perfeita, também se identificava

${ }^{12} \mathrm{Na}$ mesma linha ver J. RUIZ DE GOPEGUI, “O Concílio Vaticano II quarenta anos depois”, Perspectiva Teológica 37 (2005) 11-30.

${ }_{13}$ Dezesseis anos antes o Santo Ofício ainda proibia a participação de católicos em quaisquer reuniões de caráter ecumênico! Ver P.C. BARROS, "A eclesiologia do Vaticano II e o ecumenismo", in J. BIZON / R. DRUBI (orgs.), A unidade na diversidade, S. Paulo: Loyola, 2004, p. 98.

${ }^{14}$ F. CATÃO, "O ecumenismo católico: pródromos, formulação e prospectiva de 1964 a 2004", in BIZON / DRUBI, op. cit., p. 69. 
sem mais com a Igreja de Jesus Cristo, de tal modo que fora de si só havia um vazio eclesial. Mas enquanto se descreve a si própria constituindo-se de uma pluralidade de elementos (Palavra de Deus, acolhimento na fé, ação do Espírito Santo, sacramentos, ministério ordenado), sem identificar a Igreja de Cristo consigo mesma ${ }^{15}$, abre ela a possibilidade de que alguns desses elementos possam se encontrar fora dela. Enquanto tais elementos são constitutivos da Igreja, são eles elementos eclesiais e justificam a denominação de Igrejas ou de comunidades eclesiais para além da Igreja Católica. Deste modo se reconhece poder se encontrar a Igreja de Cristo também fora da Igreja Católica, na medida em que elas possuam e atualizem os componentes eclesiais. Este Decreto retoma, assim, o que vem afirmado na Constituição Dogmática Lumen Gentium com o já famoso "subsistit in Ecclesia Catholica" (LG 8) ${ }^{16}$. Sabemos mesmo que Paulo VI promulgou no mesmo dia a Lumen Gentium e a Unitatis Redintegratio, observando que a doutrina sobre a Igreja deveria ser interpretada à luz das ulteriores explicações presentes no Decreto sobre o ecumenismo ${ }^{17}$.

Entre os elementos eclesiais presentes nas comunidades e Igrejas em questão encontram-se em primeiro lugar a fé em Jesus Cristo e sua expressão sacramental no batismo (UR 3). Fato importante diante de uma sociedade secularizada e também devido à proximidade das outras grandes religiões, que confere a todos os fiéis batizados uma visível identidade de fundo. Pois justificados pela fé no batismo estão incorporados a Cristo, ou, com outras palavras, fazem parte do Corpo de Cristo. Outros elementos presentes fora da Igreja Católica são também citados no texto conciliar: a Palavra escrita de Deus, a vida da graça, a fé, a esperança, a caridade e outros dons interiores do Espírito Santo. E o parágrafo termina incisivamente: "Tudo isso, que provém de Cristo e a Cristo conduz, pertence por direito à única Igreja de Cristo" (UR 3).

Daí serem as Comunidades e Igrejas separadas reconhecidas explicitamente como instituições salvíficas que mediatizam a graça de Deus para seus membros. A distinção feita no Decreto entre elas e a Igreja Católica diz respeito à plenitude dos meios salvíficos queridos por Deus para sua Igreja. Plenitude, portanto, não significa perfeição das instituições eclesiais, nem que haja uma perfeita correspondência entre o institucional e o espiritual na Igreja Católica. Apenas quer afirmar que a totalidade dos meios nela se encontra. Naturalmente os Padres conciliares não ignoravam que

${ }^{15} \mathrm{O}$ texto conciliar em momento algum ao descrever a Igreja de Cristo a identifica com a Igreja Católica, embora os elementos citados, sobretudo a menção aos sucessores de Pedro confirme que a Igreja de Cristo subsiste na Igreja Católica (UR 2).

${ }^{16}$ Para uma compreensão mais ampla ver o que escrevemos em "Unidad y Unicidad de la Iglesia. Iglesia, Reino de Dios y Reino de Cristo", in Comentário teológico a la declaración Dominus Jesus, Bogotá, 2001, pp. 187-225, aqui pp. 196-201.

${ }^{17}$ AAS 56 (1964) 1012s. 
mesmo no âmbito visível, sacramental, ou institucional reinavam discrepâncias entre a compreensão católica e as demais. De qualquer modo, com a idéia de plenitude e de não-plenitude na incorporação à Igreja de Cristo está intimamente conexa a afirmação de uma certa comunhão, embora não perfeita, com a Igreja Católica (UR 3). Outra conseqüência é a concepção de uma pertença ao Povo de Deus que se apresenta diversificada ${ }^{18}$. Daí a distinção entre Igrejas (ortodoxos) e Igrejas e comunidades eclesiais (instituições nascidas na Reforma), que se encontra presente no texto conciliar ${ }^{19}$.

Do que vimos podemos concluir se encontrarem nas demais Igrejas e Comunidades Eclesiais elementos da Igreja de Jesus Cristo. Como diz o próprio decreto: "É mister que os católicos reconheçam, com alegria, e estimem os bens verdadeiramente cristãos, oriundos de um patrimônio comum, que se encontram entre os irmãos separados de nós". E mais adiante: "Tudo o que a graça do Espírito Santo realiza nos irmãos separados pode contribuir também para a nossa edificação" (UR 4). Deste modo elas dispõem do que oferecer à Igreja Católica. Mas pode esta última que dispõe da plenitude dos meios salvíficos, ainda receber algo de fora? Ou mais claramente, pode a Igreja Católica mudar no diálogo ecumênico?

O texto já começa a responder a tal questão ao chamar a atenção para o caráter peregrinante da Igreja, que na esperança caminha para a pátria (UR 2). "Este povo, enquanto peregrina cá na terra, cresce incessantemente em Cristo" (UR 3). Como peregrina, a Igreja está imersa na história, participando inevitavelmente das limitações e insuficiências de qualquer realidade histórica. O que vem explicitamente mencionado pelo texto conciliar primeiro com relação à vivência cristã dos católicos. "Examinem, com espírito sincero e atento, o que dentro da própria família católica deve ser renovado e realizado, para que sua vida dê um testemunho mais fiel e luminoso da doutrina e dos ensinamentos recebidos de Cristo através dos Apóstolos" (UR 4). Caso contrário, "a face da Igreja oferece aos olhos dos irmãos de nós separados e do mundo inteiro um esplendor menor" (UR 4).

Em seguida com relação ao próprio modo de entender a doutrina cristã que pode cair em unilateralidades ou mesmo omissões por contingências históricas. A experiência provinda da participação no diálogo ecumênico revelou tais insuficiências. Estas ajudaram a aprimorar certas compreensões e ênfases parciais na exposição doutrinal e na vida da Igreja Católica. Poderíamos citar a ação do Espírito Santo, o lugar proeminente da Palavra de Deus, o sacerdócio comum dos fiéis, o caráter comunitário da liturgia, sem pretensão de sermos completos ${ }^{20}$. Como exprime o Decreto: “Tudo o

${ }^{18}$ J. FEINER, "Kommentar zum Dekret ueber den Oekumenismus", in LThK. Das Zweite Vatikanische Konzil II, Freiburg: Herder, 1967, p. 57.

${ }^{19}$ Ibidem, p. 55s.

${ }^{20}$ Ibidem, p. 68. 
que é verdadeiramente cristão jamais se opõe aos bens genuínos da fé, mas sempre pode fazer com que mais se compreenda o próprio mistério de Cristo e da Igreja" (UR 4).

Mas também do ponto de vista institucional pode a Igreja sofrer mudanças, pois enquanto instituição humana e terrena necessita de contínua reforma (UR 6). Além desta afirmação mais básica o Decreto reconhece que os elementos constitutivos da Igreja de proveniência divina se concretizam necessariamente no interior da história dentro de contextos determinados e situações existenciais particulares. "As circunstâncias das coisas e dos tempos" não se limitam ao âmbito moral, mas também ao da doutrina e da disciplina, implicando assim uma reforma também institucional ${ }^{21}$. A configuração histórica da Igreja reflete inevitavelmente uma determinada época, cultura, situação existencial. Assim o Decreto justifica a legitimidade da tradição oriental: "A herança deixada pelos Apóstolos foi aceita de formas e modos diversos e, desde os primórdios da Igreja, cá e lá, foi explicada de várias maneiras, também por causa da diversidade de gênio e condições de vida" (UR 14).

A unidade da Igreja de Cristo, meta do movimento ecumênico, não consiste num simples voltar à Igreja Católica, mas numa integração cada vez maior de todas as Igrejas e Comunidades Eclesiais que realize mais plenamente e manifeste mais perfeitamente a Igreja de Jesus Cristo (UR 4). Mesmo sem terem atingido a unidade podem as Igrejas e Comunidades Eclesiais colaborar mais efetivamente para o bem comum (UR 4) na obediência à consciência cristã, pois sejam os problemas e tarefas, sejam os imperativos éticos decorrentes da fé, são afinal comuns a todas. Naturalmente uma maior unidade do próprio cristianismo reverterá em sua maior credibilidade em face das outras religiões.

Dentro da perspectiva adotada neste estudo este Decreto sobre o Ecumenismo confirma nossa hipótese inicial da íntima conexão entre diálogo e aggiornamento. Este último é mais profundo do que uma simples atualização ou modernização da Igreja. O Decreto fala de renovação (renovatio) e de reforma (reformatio) sem diferenciar muito uma da outra, embora tenham conotação diversa no uso da tradição e do magistério. Reforma implica reconstituição à semelhança de uma era anterior, deformada pelo pecado humano, como a entendeu o século XVI deixando-se iluminar pela época patrística. Já renovação concerne uma atitude de fundo, que busca mais fiel e profundamente viver o Evangelho ${ }^{22}$. Ambas as conotações estão presentes no termo aggiornamento. Ao entrar no diálogo ecumênico a Igreja Católica entrava inevitavelmente numa época de reno-

${ }^{21}$ Ibidem, p. 72.

${ }^{22}$ Ibidem, p. 71 nota 23. 
vação e de reforma. Pois no diálogo ecumênico "todos examinam sua fidelidade à vontade de Cristo acerca da Igreja e, na medida do necessário, iniciam vigorosamente o trabalho de renovação e de reforma" (UR 4).

O diálogo ecumênico vivido seriamente pressupõe um adequado conhecimento do interlocutor e de sua Igreja ou Comunidade Eclesial (UR 4). Na reflexão teológica sobre a revelação, os dados provindos de fora também deverão ser considerados pelo teólogo, constituindo-se mesmo como um novo horizonte de compreensão, como um novo paradigma para a compreensão da fé. É o que já foi chamado de "hermenêutica da unidade"23. Naturalmente esta nova perspectiva, que já começa a dar frutos ${ }^{24}$, não deixará de enriquecer a Igreja Católica ampliando sua catolicidade e favorecendo a unidade almejada.

\section{O diálogo inter-religioso}

O objetivo pastoral do Concílio Vaticano II, já anteriormente mencionado e explicitado, aparece claramente na nova atitude diante das religiões não cristãs. No passado, em nome da verdade cristã, estas religiões eram vistas pelo cristianismo como realidades inferiores, cheias de falsidades e degenerações, que deveriam desaparecer para que se impusesse a única verdade da fé cristã ${ }^{25}$. Já o texto da Declaração Nostra Aetate pretende conhecer, compreender, dialogar e cooperar com as demais religiões num clima de respeito e de estima recíprocas, excluindo qualquer tipo de discriminação entre os seres humanos com base em raça, classe social ou religião (NA 5). Não só se considera, sem depreciação, os membros das outras religiões, mas também as mesmas enquanto tais. Este fato significa sem dúvida um progresso ${ }^{26}$.

O fundamento teológico aparece explícito: "Todos os povos, com efeito, constituem uma só comunidade. Têm uma origem comum, uma vez que Deus fez todo o gênero humano habitar a face da terra. Têm igualmente um único fim comum, Deus, cuja providência, testemunhos de bondade, e planos de salvação, abarcam a todos" (NA 1). Além disso, esta Declaração,

${ }^{23}$ R. GIRAULT, "La réception de l'Oecumenisme", in ALBERIGO / JOSSUA, op. cit., p. 213.

${ }^{24}$ Ver J.M.R. TILLARD, "L'eucharistie sacrement de l'Église communion", in B. LAURET / F. REFOULÉ (orgs.), Initiation à la pratique de la théologie III, Paris: Cerf, 1993, pp. 437-463; B. SESBOUÉ, Pour une théologie oecuménique, Paris: Cerf, 1990.

${ }^{25}$ A.-M. HENRY, "Liminaire", in A.-M. HENRY (org.), Les relations de l'Église avec les religions non chrétiennes. Déclaration "Nostra Aetate”, Paris: Cerf, 1966, p. 13.

${ }^{26}$ F. TEIXEIRA, "O Concílio Vaticano II e o diálogo inter-religioso", in LOPES GONÇALVES / BOMBONATTO (orgs.), op. cit., p. 288. 
um dos últimos textos do Concílio a ser confeccionado, recebeu importantes contribuições teológicas de textos precedentes, como a da ação universal da graça (GS 22; LG 16).

Também ele vem marcado por um otimismo salvífico presente em outros textos conciliares que dizem respeito à salvação dos não cristãos. O que no passado aparecia apenas como uma possibilidade baseada na misericórdia divina, vem neste Concílio incisivamente afirmado. "Com efeito, tendo Cristo morrido por todos e sendo uma só a vocação última do homem, isto é, divina, devemos admitir que o Espírito Santo oferece a todos a possibilidade de se associarem, de modo conhecido por Deus, a este mistério pascal" (GS 22). Mais cautelosos se mostram os Padres conciliares quando tratam de avaliar teologicamente as religiões. Eles reconhecem em seus ritos valores (LG 17; AG 9), em suas tradições preciosos elementos religiosos e humanos (GS 92), ou as sementes do Verbo aí ocultas (AG 11), ou ainda a presença de verdade e da graça nas nações como secreta presença de Deus (AG 9).

Estas afirmações positivas se encontram de certo modo equilibradas pela observação freqüentemente repetida de que tais componentes religiosos devem ser sanados, elevados e aperfeiçoados (LG 17). Pois a Igreja ao assumi-los os purifica, fortifica e eleva (LG 13), liberta-os dos contágios malignos (AG 9). E mais taxativamente: "Ao mesmo tempo à luz do Evangelho procurem iluminar, libertar e submeter essas riquezas ao domínio de Deus Salvador" (AG 11). Pois a Declaração Nostra Aetate reconhece que os modos de agir e de viver, os preceitos e as doutrinas das demais religiões estejam em muitos pontos em desacordo com a fé cristã (NA 2).

Contudo, o posicionamento positivo do Concílio em face das outras religiões deixa sem resposta perguntas já presentes na mente de vários participantes, como, por exemplo, o significado das mesmas no desígnio salvífico de Deus. No mesmo sentido permanece obscura a problemática da verdade da religião cristã em face das outras religiões ou a questão dos critérios para discernir o que é bom e verdadeiro nas mesmas ${ }^{27}$. Só valeriam critérios cristãos? Mais séria é a questão sobre a capacidade salvífica de tais religiões. São elas mediações de salvação para seus membros?28

Porém o fato de não terem abordado questões teológicas sobre o valor e a autonomia salvífica das demais religiões, tema que ocupará os estudiosos nas décadas posteriores, não impediu que os Padres conciliares recomendassem o diálogo com as religiões não cristãs (GS 92). O diálogo facilitará

${ }^{27}$ D. RACCA, "Il dialogo interreligioso nel Concilio Vaticano II: aperture e limiti", Rassegna di Teologia 38 (1997) 637-663, aqui p. 662.

${ }^{28}$ J. DUPUIS, Vers une théologie chrétienne du pluralisme religieux, Paris: Cerf, 1997, p. 243. 
o conhecimento mútuo, a descoberta de valores comuns, a colaboração em vista da paz e da justiça no mundo (AG 11; 34). O Concílio exorta os católicos não só a reconhecer tais valores, mas ainda a manter e desenvolver "os bens espirituais e morais como também os valores sócio-culturais" presentes nas outras religiões (NA 2). Por outro lado, o Concílio deixa em aberto a questão sobre se tais bens possam ou não ser encontrados também na Igreja ${ }^{29}$. Pois dialogar implica não só dar, mas também receber. Teria o cristianismo algo a receber das outras religiões? Aí está uma questão que não foi respondida no Vaticano II.

De qualquer modo, entretanto, o diálogo inter-religioso representa para o Concílio não só um componente essencial para a evangelização, como também não deixará de repercutir para dentro do cristianismo. Pois conhecer e respeitar o diferente, sem procurar destruí-lo como uma ameaça à própria identidade, já implica se ver questionado nas próprias convicções, revendo-as à luz dos dados provindos de fora. É o que já foi caracterizado como o diálogo intra-religioso ${ }^{30}$, anterior mesmo ao diálogo inter-religioso tal como o conhecemos.

\section{O diálogo com a cultura}

Certamente o fator mais importante que levou João XXIII a enfrentar o desafio do aggiornamento para a Igreja foi o hiato, construído ao longo de séculos, entre Igreja e sociedade e mais concretamente entre Igreja e cultura hodierna ${ }^{31}$. Esta preocupação esteve presente também entre os Padres conciliares, como nos atestam os numerosos textos sobre esta questão, encontrados em diversos documentos. O Concílio Vaticano II, mesmo sem apresentar uma compreensão da relação fé e cultura, tal como a temos hoje, representa uma tomada de consciência inédita na história da Igreja, que irá desencadear todo um processo de reflexão e de ação nos anos posteriores.

Para demonstrar a importância central da cultura na vida humana ele se afasta de uma concepção elitista da mesma, assumindo uma perspectiva de cunho antropológico. A cultura desenvolve as qualidades corpóreas e espirituais do ser humano, subjuga a natureza, constrói a vida social, expressa conquistas históricas. A cultura manifesta como um grupo humano se entende, se organiza, se desenvolve num determinado contexto social

${ }^{29}$ H. MAURIER, "Lecture de la déclaration par un missionarie d'Afrique", in HENRY (org.), op. cit., p.133s.

${ }^{30}$ R. PANIKKAR, The Intra-Religious Dialogue, New York: Paulist Press, 1978.

${ }^{31}$ A. DONDEYNE, "L'essor de la culture", in Y. CONGAR / M. PEUCHMARD (orgs.), L'Église dans le monde de ce temps. Tome II, Paris: Cerf, 1967, p. 458. 
(GS 53). Este fato ocasiona não só uma pluralidade de culturas, mas também mudanças contínuas nas mesmas ao longo da história (GS 54). As mudanças culturais dos últimos tempos não passaram desapercebidas aos participantes do Concílio, como atesta a descrição que delas faz um texto da Gaudium et Spes, onde já se vislumbra o que hoje chamamos de globalização (GS 54). Também a dificuldade de uma síntese do conhecimento pela enorme produção de dados culturais não deixou de ser observada pelos Padres conciliares (GS 61).

A cultura, assim como as demais realidades humanas, possui um "valor próprio", está a serviço da "vocação integral do homem", e também se viu atingida pelo pecado (AA 7). Por outro lado, ela goza de liberdade para se desenvolver e de autonomia para atuar, desde que respeite os direitos da pessoa e da comunidade humana (GS 59). Na medida em que não satisfaz esta condição, se tornando um obstáculo à realização última do ser humano, deve a cultura sofrer correções e aperfeiçoamentos (LG 17; AA 7).

A intima relação entre fé e cultura tem seu fundamento teológico com a própria encarnação de Cristo nas "condições sociais e culturais" do contexto onde viveu (AG 10). Observa-se também que Deus sempre se revelou "de acordo com a cultura própria de diversas épocas" (GS 58). Igualmente a Igreja sempre se serviu das culturas na proclamação da mensagem evangélica, na celebração litúrgica e na vida da comunidade eclesial, embora sem se identificar com cultura alguma (GS 44; 58). Pois há uma distinção entre o depósito da fé e o modo de apresentá-la, mantendo-se a identidade da mensagem cristã (GS 62), embora esta afirmação apareça hoje mais complexa do que parecia então. De qualquer modo a inevitável expressão da fé sempre num determinado contexto sócio-cultural exige da reflexão teológica uma atualização permanente (GS 62), uma formação presbiteral "conforme os costumes de cada povo" (AG 16) e "cursos e congressos adaptados às condições de cada território" (PO 19). Também os leigos devem manifestar sua vida cristã "no âmbito da sociedade e da cultura pátrias, segundo as suas tradições nacionais. Devem conhecer esta cultura, purificá-la e conservá-la, desenvolvê-la segundo as recentes situações, e finalmente aperfeiçoá-la em Cristo" (AG 21).

Mas não só na expressão e na celebração da fé cristã se revela a cultura como fator importante para a Igreja. Pois não são apenas as culturas que no contato com a fé cristã aprofundam, corrigem e aperfeiçoam o que lhes é próprio. Igualmente a Igreja "tendo uma estrutura social visível... se enriquece também com a evolução da vida humana social... para conhecêla mais profundamente, melhor exprimi-la e adaptá-la de modo mais feliz aos nossos tempos" (GS 44). Observemos expressamente que o Concílio tem em vista não só a inculturação da mensagem salvífica, mas a própria Igreja em sua dimensão institucional. Por isso mesmo o contato com a cultura local poderá abrir "caminhos para uma mais profunda adaptação 
em todo o âmbito da vida cristã" (AG 22) ${ }^{32}$. Como conseqüência teremos configurações específicas de Igrejas particulares que, enquanto ornadas com suas tradições próprias, terão seu lugar na comunhão eclesial (AG 22). Só assim poderão elas se enraizar profundamente num povo (AG 15).

\section{O tempo pós-conciliar}

O Concílio Vaticano II, como já vimos no início desta reflexão, representa o fim de uma era e o começo de uma nova etapa na vida da Igreja. Como a continuidade e a novidade sempre caminham juntas, conforme a sensibilidade de cada um, esta característica de ter sido um Concílio-evento suscitará naturalmente interpretações diversas. E também expectativas, nem sempre muito realistas, que deram lugar a uma fase de desânimo e pessimismo depois dos primeiros anos de entusiasmo e otimismo. Já os estudiosos dos Concílios Ecumênicos observam que nenhum deles foi seguido de uma recepção tranqüila e unânime. Pelo contrário, por implicarem mudanças despertaram medos e resistências, geraram crises e tensões. Não é deveras simples desfazer-se de hábitos arraigados, de mentalidades familiares, de práticas longevas. Acolher o novo implica inevitavelmente coragem e risco.

Creio que a melhor leitura deste período pós-conciliar é aquela que realisticamente o interpreta como um tempo de iniciativas e de omissões, de avanços e de recuos, de conservação e de novidade. Sem dúvida alguma é uma época marcada por tensões e embates, uma época de crise enquanto conseqüência natural de mudanças doutrinais ou institucionais. Mas também, como já foi agudamente observado, uma época de aprendizado e de lenta gestação de uma nova configuração eclesial. E isto não é, sem dúvida alguma, algo simples e realizável em poucos anos ${ }^{33}$. Fundamental aqui é conseguir ver para além dos fatos e das disputas um avanço persistente na recepção dos anseios conciliares, mesmo que diminuídos, dificultados, sujeitos a outras leituras, traduzidos melhor ou pior em realidades concretas. É fundamental ter consciência disso ao abordarmos brevemente a repercussão real na vida da Igreja do que nos ensinaram os textos conciliares. E também não perder de vista a nossa perspectiva na linha do aggiornamento e do diálogo.

Com relação ao diálogo ecumênico passos importantes foram dados ${ }^{34}$ desde os encontros de Paulo VI com o patriarca Atenágoras e com o Dr.

${ }^{32} \mathrm{O}$ itálico é nosso.

${ }^{33}$ G. ROUTHIER, "A 40 anni dal Concilio Vaticano II. Un lungo tirocinio verso un nuovo tipo di cattolicesimo”, La Scuola Cattolica 133 (2005) 19-52, aqui p. 24s.

${ }^{34}$ R. GIRAULT, art. cit., p. 187-226. 
Ramsey, o fim dos anátemas recíprocos com os ortodoxos, a colaboração com o grupo "Fé e Constituição", a participação no Conselho Mundial das Igrejas em Nova Delhi, a criação de Centros Ecumênicos com suas revistas, os textos do grupo de Dombes, a criação da Comissão Internacional Anglicano-Católica Romana (ARCIC), os trabalhos conjuntos com a Federação Luterana Mundial, a presença da Igreja Católica na assembléia do Conselho Mundial das Igrejas em Nairobi (1975) e em Vancouver (1983), os estudos em conjunto com a Igreja Anglicana sobre a Eucaristia, os Ministérios e a Autoridade na Igreja, o texto da Fé e Constituição sobre o batismo, a eucaristia e o ministério, conhecido como o texto de Lima (1982), a Encíclica Ut unum sint de João Paulo II (1995), a Declaração Conjunta sobre a Doutrina da Justificação por parte da Igreja Católica Romana e da Federação Luterana Mundial (1999).

Também aconteceram momentos críticos, como por ocasião da publicação da Declaração Dominus Jesus (2000), pelo modo como expressou a doutrina conciliar sem ter em consideração a rica evolução ecumênica do período pós-concíliar. Igualmente certa centralização romana efetuada durante o pontificado de João Paulo II dificultou sobremaneira o ecumenismo, dada a figura concreta do sucessor de Pedro que dela emerge, como o reconheceu o próprio João Paulo II em sua mencionada Encíclica. Os pontos doutrinais que ainda impedem a união desejada estão estimulando estudos importantes, maior conhecimento mútuo, depuração de configurações históricas contextuais e, sobretudo, uma compreensão mais profunda do dado revelado. Assim a noção de Igreja, de sacramento, da eucaristia, da sucessão apostólica, do ministério petrino, de ministério ordenado, para citar alguns destes pontos em litígio.

Como podemos constatar, o diálogo ecumênico contribui fortemente para o aggiornamento desejado por João XXIII. Ao interpretar a Palavra de Deus a Igreja Católica leva em consideração também a perspectiva oferecida pelas outras Igrejas e Comunidades Eclesiais. Este procedimento pressupõe que a leitura católica tradicional está inevitavelmente situada no interior da história, condicionada por conjunturas concretas, podendo, portanto, receber compreensões e expressões mais adequadas sem perder sua verdade. $\mathrm{O}$ diálogo ecumênico proporciona uma volta às fontes que, levada com objetividade, conduz sempre mais seus participantes para a verdade cristã. Naturalmente esta renovada compreensão doutrinal terá conseqüências para a liturgia, a disciplina eclesial, a organização eclesial, a figura do leigo, o ministério presbiteral, enfim, para uma nova configuração institucional da própria Igreja.

Também o tema do diálogo inter-religioso apresentou um rico desenvolvimento na época pós-conciliar, especialmente devido aos pronunciamentos de João Paulo II. Já no início de seu pontificado ele acentua a linha de Gaudium et Spes atribuindo ao Espírito Santo a firmeza encontrada nos 
adeptos de outras religiões (Redemptor hominis 6), ou mesmo a oração presente no coração de toda pessoa ${ }^{35}$, ou ainda a ação salvífica de Deus antes da era cristã e para além da Igreja (Dominum et vivificantem 53), aludindo ao texto de Gaudium et Spes 22. A Encíclica Redemptoris missio representa um passo avante, pois reconhece que "a presença e a atividade do Espírito não digam respeito somente aos indivíduos, mas à sociedade e à história, aos povos, às culturas, às religiões" (RM 28).

Um documento, emanado conjuntamente pelo Pontifício Conselho para o Diálogo Inter-Religioso e pela Congregação para a Evangelização dos Povos no ano de 1991, faz avançar ainda mais o reconhecimento das demais religiões como tais, ao afirmar que "muitas pessoas sinceras, inspiradas pelo Espírito de Deus, assinalaram certamente com a sua marca a elaboração e o desenvolvimento das suas respectivas tradições religiosas", embora sem implicar que tudo nelas seja bom (Diálogo e Anúncio 30). Estas tradições são de certo modo valorizadas enquanto ajudam seus adeptos a receberem a salvação de Jesus Cristo "na prática do que é bom nas suas próprias tradições religiosas e seguindo os ditames da sua consciência" (DA 29).

E mais adiante este importante documento reafirma, por um lado, que não se deve entrar no diálogo sacrificando as próprias convicções; por outro, reconhece que os cristãos individualmente não gozam da garantia de terem assimilado a plenitude da verdade recebida de Jesus Cristo. Pois se trata de um processo sem fim. Mantendo sua identidade podem os cristãos aprender e receber dos outros os valores positivos de suas tradições. Este diálogo inter-religioso poderá mesmo ajudar na purificação da própria fé (DA 49). Poderíamos acrescentar nem individualmente, nem coletivamente, porque na tradição dos Apóstolos "cresce, com efeito, a compreensão tanto das coisas como das palavras transmitidas", de tal modo que a Igreja "tende continuamente à plenitude da verdade divina" (Dei Verbum 8). Por trás deste texto está a característica peculiar da verdade cristãa ${ }^{36}$, pois só podemos expressar Deus de modo análogo e fragmentado, como já notara S. Paulo: "agora vemos em espelho e de modo confuso" e o nosso "conhecimento é limitado" (1Cor 13,12).

Afirmar que a revelação de Deus foi definitiva em Jesus Cristo não exclui que a expressão desta verdade possa se desvelar ao longo da história, aprofundando-se, esclarecendo-se e completando-se a partir de várias perspectivas e situações, provindas também de outras religiões. Porém a teologia cristã das religiões se encontra diante de uma questão que ainda busca uma resposta adequada. Como conciliar a afirmação de que Jesus

${ }^{35}$ Alocução à Cúria Romana antes da celebração do Natal, La Documentation Catholique 84 (1987) 133-136, aqui p. 136.

${ }^{36}$ M. FRANÇA MIRANDA, "Verdade cristã e pluralismo religioso", Atualidade Teológica 7 (2003) 32-49. 
Cristo é o único e universal salvador da humanidade com um reconhecimento da autonomia salvífica também das outras religiões não cristãs? Fundamental aqui é a abertura da Igreja para as demais religiões, não só respeitando-as em sua identidade, mas ainda unindo-se com elas para a tarefa comum pela paz e pela justiça no mundo, voltado para os bens materiais e dominado pela racionalidade fria e desumana da economia. Deste modo, o diálogo inter-religioso também repercute no interior da Igreja purificando-a, renovando-a e adequando-a melhor a sua missão salvífica para a humanidade.

O tema do diálogo da Igreja com a cultura, já presente em vários textos conciliares, como vimos anteriormente, irá receber uma mais completa compreensão nos anos seguintes. A Exortação Apostólica Evangelii Nuntiandi recomenda às Igrejas Particulares que anunciem o Evangelho na linguagem local (EN 63) e o Documento de Puebla trata com competência deste tema, acentuando mais a evangelização da cultura, sem descurar, entretanto a inculturação da fé (Puebla 385-443). O ensinamento de João Paulo II representa um avanço significativo com relação a esta temática. De fato, este papa demonstra grande sensibilidade para com o fator cultural na obra da evangelização, ao enfatizá-lo na transmissão da fé (Catechesi Tradendae 53), na obra missionária de Cirilo e Metódio (Slavorum Apostoli 19) e ao falar para o Pontifício Conselho para a Cultura (20/05/1982), quando então afirma que "uma fé que não se torna cultura é uma fé que não foi plenamente recebida, não inteiramente pensada, não fielmente vivida".

Em 1988 a Comissão Teológica Internacional oferece um texto sobre $A$ Fé e a Inculturação com uma exposição bem estruturada do tema. A Encíclica Redemptoris Missio demonstra uma compreensão mais ampla desta matéria, distinguindo a inculturação da fé da evangelização da cultura, reconhecendo que o processo estimula a Igreja "a uma renovação contínua", desde que permaneça compatível com o Evangelho e em comunhão com a Igreja Universal, sendo este processo tarefa de todo o Povo de Deus (RM 53). A Exortação Pós-Sinodal Ecclesia in Africa vê na inculturação da fé uma prioridade e uma urgência na vida da Igreja deste continente (78), enquanto a Exortação Ecclesia in America insiste mais na evangelização da cultura (70). Já a Exortação Ecclesia in Asia oferece uma boa síntese do tema (21).

Naturalmente são as Igrejas do Terceiro Mundo que demonstram melhor a importância desta temática, estudando-a em sua complexidade, aplicando-a à intelecção e expressão da fé, à celebração litúrgica, à atividade pastoral, à espiritualidade. Constata-se que as culturas nativas estão embebidas de componentes religiosos. Este fato exige um maior discernimento na utilização dos elementos culturais do contexto. Mas também as Igrejas do Primeiro Mundo, por estarem às voltas com uma sociedade pluralista e secularizada, sentem em si próprias a necessidade urgente deste diálogo da fé com a cultura. $\mathrm{O}$ tema se torna verdadeiramente universal. 
Como aparece desta breve resenha, o diálogo fé-cultura não só reverte em proveito para as culturas nativas, mas ainda ajuda à Igreja em sua missão salvífica. Inculturação da fé e evangelização das culturas caminham sempre juntas. A consciência atual da Igreja com relação a esta realidade, que sempre esteve presente ao longo de sua história, confirma a intuição de João XXIII: o aggiornamento da Igreja passa pelo diálogo com a sociedade, que sem deixar de ser crítico sabe dela aprender para ser, de fato, sacramento da salvação de Jesus Cristo. Para tal ela deve não só se fazer entender em sua proclamação, mas também saber se configurar como instituição, naturalmente sem sacrificar sua identidade teológica recebida de Deus.

\section{Diálogo e aggiornamento na Igreja do Brasil}

Primeiramente façamos certas observações iniciais. A recepção do Concílio Vaticano II na Igreja do Brasil está intimamente relacionada com as Assembléias Gerais do CELAM, sobretudo as de Medellín e de Puebla, nas quais os representantes de nosso episcopado tiveram forte influência. Notemos também certas características peculiares de nosso país que facilitam ou dificultam o acolhimento da renovação conciliar e que irão se refletir nos três diálogos tratados neste estudo. $\mathrm{O}$ enorme tamanho do território brasileiro, a diversidade cultural nas várias regiões, a ausência de uma evangelização séria no passado, o fato de o catolicismo ter sido sempre uma religião majoritária, favorecendo uma pastoral de manutenção e uma religião tradicional, são elementos que dificultaram a recepção do Concílio. Por outro lado, o fato de sermos uma jovem nação, aberta ao futuro, pressionada por urgentes problemas sociais, atravessada por aceleradas mudanças culturais e transformada por um crescente processo de secularização, representa estímulo e motivação para uma renovação eclesial.

O diálogo ecumênico em decorrência do Decreto Unitatis redintegratio significou um dado novo na Igreja Católica do Brasil, sobretudo a nível institucional, como a criação do setor de ecumenismo da CNBB, a semana de oração pela unidade dos cristãos, o surgimento do Conselho Nacional de Igrejas Cristãs (CONIC), a inclusão do ecumenismo nos Planos de Pastoral de Conjunto da CNBB ou em algumas Campanhas da Fraternidade. Com variações bem significativas conforme as regiões do país, o avanço do espírito ecumênico entre os católicos foi, de um modo geral, modesto. Constituem exceções iniciativas ecumênicas como o CESEP ou o CEBI, para citar algumas ${ }^{37}$. Ajudou muito o trabalho conjunto por uma sociedade mais justa na linha da libertação cristã. A entrada do pentecostalismo signifi-

\footnotetext{
${ }^{37}$ Para uma exposição mais completa ver E. WOLFF, "A recepção do Decreto Unitatis redintegratio no Brasil”, in BIZON / DRUBI, op. cit., pp. 23-53.
} 
cou mais um componente complicador no ideal ecumênico, que não é por ele aceito. O sucesso pentecostal desfigurou a imagem do protestantismo histórico e não deixou de repercutir no interior da própria Igreja Católica.

O diálogo inter-religioso num país maciçamente cristão se tornou mais uma tema para teólogos, incentivados pelo surgimento de institutos destinados a Ciências da Religião, do que propriamente um diálogo motivado por necessidades pastorais. Neste sentido predominam as discussões sobre publicações do Primeiro Mundo. Por outro lado não nos faltam problemáticas bem nossas a pedir reflexões urgentes e soluções pastorais. As religiões africanas, já reconhecidas em seus direitos, são assumidas também por católicos, desafiando assim os padrões clássicos de pertença religiosa, sem que possamos incluir tal comportamento num sincretismo objetivo. Lamentamos que os estudos em curso, que não são poucos, permaneçam no âmbito da sociologia ou da fenomenologia religiosa e não alcancem o nível propriamente teológico onde poderia se dar o diálogo inter-religioso.

O diálogo com a cultura se mostra também complexo. Pois, de um lado temos no país uma diversidade cultural que constitui uma grande riqueza, mas que não encontra acolhimento oficial nas expressões da fé, nas práticas de culto, nas pastorais da Igreja. Aqui, como em outros países, a tarefa de inculturação desencadeada nos pronunciamentos de João Paulo II se viu tolhida pelas medidas disciplinares provindas da Santa Sé. Deste modo, a inculturação realmente bem sucedida, embora sempre sujeita a correções como qualquer realidade humana, se encontra mais na religiosidade popular, como reconhece o Documento de Santo Domingo (36) ${ }^{38}$. Ao contrário do que acontece na África e na Ásia, dotadas de culturas nativas bem diversas da cultura ocidental, temos uma cultura híbrida com componentes europeus, africanos e indígenas, com forte predominância do fator ocidental, fato este que dificulta também a devida inculturação da fé.

\section{Conclusão}

A pastoralidade do Concílio Vaticano II caracteriza o que ele tem de próprio, distinguindo-o dos demais Concílios anteriores. Esta característica se concretiza nos dois termos diálogo e aggiornamento. Deste modo este Concílio desencadeia na Igreja um processo constante para que ela consiga, de fato, transparecer em sua vida e em sua proclamação a mensagem salvífica de Jesus Cristo, para que ela seja, de fato, e não apenas teologicamente, o sacramento da salvação para a humanidade. Este processo implica compreensões mais adequadas da própria fé, expressões mais atualizadas

${ }^{38}$ Ver M. FRANÇA MIRANDA, Inculturação da fé. Uma abordagem teológica, S. Paulo: Loyola, 2001, pp. 129-147. 
do Evangelho, instituições mais condizentes com a época. Posto em movimento traria certamente uma configuração eclesial que respondesse aos desafios do tempo e da sociedade, como já aconteceu no passado ${ }^{39}$.

Sabemos já, depois de quarenta anos, quão difícil e complexa é esta tarefa de uma recepção criativa do Concílio. As razões já nos são de certo modo conhecidas: diferentes linhas teológicas presentes nos próprios textos conciliares, simplificações e abusos na aplicação do Concílio, ação da Cúria Romana a favor da linha minoritária durante o Concílio, a natural resistência a qualquer mudança, a dificuldade de se expressar dados teológicos em categorias institucionais e jurídicas, a rapidez das transformações sócioculturais com a emergência de novos desafios ${ }^{40}$. Certamente ainda outras poderiam ser aduzidas, mas todas elas não nos dispensam de continuar lutando por uma recepção criativa e localizada das linhas mestras deste Concílio para a Igreja do Brasil. Pois as três modalidades de diálogo que nos ocuparam nesta reflexão, não só acontecem em nosso país, não só constituem também para nós autênticos desafios, mas também provocam transformações na mentalidade e na instituição eclesial características de nossa Igreja.

O diálogo ecumênico deverá enfatizar a fé na pessoa de Jesus Cristo. Seja devido à carente evangelização dos cristãos no Brasil, seja pela diluição e deformação da própria fé cristã, submetida a leituras de cunho neoliberal, a manipulações para fins políticos, a sincretismos de auto-ajuda. Diante de uma sociedade em processo crescente de secularização, com a ameaça da indiferença religiosa já dominante em alguns países europeus, faz-se mister enfatizar a consciente opção da fé em Jesus Cristo, sentido último da vida humana e patrimônio comum dos cristãos. Implicada nesta fé que nos leva ao amor fraterno está a luta pela justiça e o cuidado com os excluídos da sociedade, frente de batalha comum como já vem se dando. Num tempo de cristandade católicos e evangélicos podiam acentuar mais suas diferenças e se combaterem mutuamente. Numa época de rápida descristianização eles devem enfatizar mais os pontos comuns e se ajudarem mutuamente. O que não deixará de repercutir na configuração destas comunidades eclesiais. Não nos compete resolver daqui as desavenças originadas no Primeiro Mundo, tarefa já em curso naquelas Igrejas.

O diálogo com as religiões deverá levar mais a sério o conhecimento das religiões africanas e indígenas do Brasil. Ambas já tiveram vários de seus elementos assimilados pela religiosidade popular católica, apesar dos esforços contrários da hierarquia. O diálogo com as mesmas é uma tarefa mais importante para nós do que com as milenares religiões asiáticas ou mesmo com o judaísmo ou com o islamismo. Elas já entraram profundamente na cultura brasileira, já fazem parte de nosso universo simbólico e do nosso

${ }^{39}$ Y. CONGAR, L'Église de saint Augustin à l époque moderne, Paris: Cerf, 1970.

${ }^{40}$ G. ALBERIGO, "Fedeltà e creatività nella ricezione del concilio Vaticano II. Criteri ermeneutici”, Cristianesimo nella Storia 21 (2000) 383-402. 
ethos. Na medida em que sua perspectiva de leitura fosse aproveitada para a fé cristã, ela certamente nos ajudaria num aggiornamento da mensagem evangélica condizente com a mentalidade religiosa de nosso povo.

O aggiornamento na linha cultural implica um maior reconhecimento das diversidades culturais de cada região deste país continental. Uma tarefa própria dos regionais da CNBB, que deveriam gozar de quadros competentes e de liberdade de ação para fazer com que os brasileiros possam viver e expressar sua fé a partir da respectiva cultura, responsável por sua própria identidade. Com isso não se negam os componentes culturais nacionais, assimilados, num segundo momento, pelos brasileiros e que nos caracterizam aos olhos dos estrangeiros. Outro ponto significativo vem a ser a sociedade pluralista em que vivemos, que não mais aceita o catolicismo como componente interno do patrimônio cultural transmitido. A Igreja, por conseguinte, deverá ser mais ativa na ação missionária dentro do país e reforçar a dimensão comunitária da fé que contrabalance o impacto de se sentirem minoria por parte dos católicos conscientes. Dado que a maioria da nossa população é constituída pelos pobres, também no futuro a Igreja deverá prosseguir sua opção preferencial por eles, como já o vem fazendo.

Para este aggiornamento a reflexão teológica local tem papel decisivo para fundamentar as opções pastorais do episcopado. Naturalmente, sejam os subsídios teológicos, sejam os compromissos pastorais, pressupõem equilíbrio e discernimento, respeito pelos juízos diferentes, comunhão com a Igreja Universal, maior participação do Povo de Deus, grande confiança em Deus e, sobretudo, aceitação do mistério pascal como a verdade última da nossa vida e da vida pastoral da Igreja. De fato, mais do que as teologias, recursos e poderes humanos, a Igreja avança na história fundamentada num Messias crucificado e ressuscitado, "força e sabedoria de Deus" (1Cor 1,24).

Mario de França Miranda, SJ, é doutor em teologia pela Pontifícia Universidade Gregoriana (Roma). Atualmente é professor de teologia sistemática na Pontifícia Universidade Católica (Rio de Janeiro). Publicou entre muitos livros e artigos: O Mistério de Deus em nossa vida, São Paulo: Loyola, 1975; O cristianismo em face das religiões, São Paulo: Loyola, 1998; Inculturação da fé: uma abordagem teológica, São Paulo: Loyola, 2001; A salvação de Jesus Cristo: doutrina da Graça, São Paulo: Loyola, 2004; Existência cristã hoje, São Paulo: Loyola, 2005.

Endereço: R. Marquês de São Vicente, 389

22451-041 Rio de Janeiro - RJ

e-mail: mfranca@rdc.puc-rio.br 